\title{
KAKO DO ZNANJA V EKONOMIII ZNANJA - RAZMIŠLJANJE OB BRANJU
}

Daniele Blondel: LINNOVATION POUR LE MEILLEUR ET POUR LE PIRE, Hatier, coll. Actualités de l'économie mondiale, Paris, 1990.

Že Paolo Freire v Pedagogiki zatiranih in Eduard Lindeman v Pomenu izobraževanja odraslih opozorita, da je v razslojeni družbi tudi znanje neenakomerno porazdeljeno. Medtem ko so nekateri prepričani, da so nezaposljivi in do znanja in izobrazbe nimajo pravice, se drugim zdi, da jim pripadata. ${ }^{1}$

Danes, ko smo na prehodu iz družbe dela (angl. labor society) v đružbo znanja (angl. knowledge society) pa tudi družbo kulture in vseživljenjskega izobraževanja, bi bilo naravno želeti si, da bi znanje imeli vsi. Sanjamo o učeči se družbi, kjer bi imeli dostop do izobraževanja odraslih vsi, ne glede na spol, starost, družbeno poreklo, raso, religijo in druge distinktivne značilnosti. Še več, sa-

\section{Znanje $v$ razslojeni družbi je neenako- merno porazde- ljeno.} njamo o zdravi družbi, takšni, ki bi znala čim bolje uporabiti sposobnosti in znanja vseh svojih članov. Sanje se ne uresničujejo in priča smo številnim vrstam neenakosti. $V$ teh okoliščinah je naloga izobraževalcev odraslih, da omogočajo pridobivanje znanja. Še več, da gradijo mostove med kulturo ljudi in družbenih skupin in tisto kulturo, ki najbolj omogoča družbeni razvoj.

Podobno razmišljajo ekonomisti, med njimi Daniele Blondel, profesorica ekonomije na
Univerzi Paris IX - Dauphine, predavateljica na Šoli za družbene vede (fr. L' Ecole des hautes études en sciences sociales) in avtorica del s področja ekonomije in visokega šolstva. Po temeljni izobrazbi je ekonomistka, zanima pa jo razmerje med inovacijami, gospodarsko rastjo in zaposlovanjem. Še več, zanima jo vloga znanja $v$ novi ekonomiji, $\mathrm{ki}$ jo imenuje ekonomija znanja. Prisluhnili smo njenemu predavanju na Univerzi vseh znanj (L'Université de tous les savoirs), prebrali smo njene številne članke in nekatera dela ter kritično povzeli njene misli ali bolje teze, ki so zanimive tudi za našo obravnavo problemov.

\section{KAM SE SELIJO VIRI ZNANJA?}

Daniele Blondel se ukvarja z vprašanjem svetovne delitve kognitivnih virov. Pravi, da se morda to vprašanje na prvi pogled zdi prazno in nesmiselno, kajti ko govorimo o kognitvnih virih, imamo $v$ mislih znanje, to pa lahko označuje tudi znanost ali izdelke znanosti. Znanost, ki že po svoji naravi ne pozna meja in je univerzalna.

Še več, kadar gre za kognitivine vire, se zdi, da delitev ni primeren izraz. Delimo navadno nekaj, česar ni dovolj, kar je redko. Stvarne dobrine lahko delimo in jih razporedimo med druge. Tisti, ki prejmejo, denimo kolač, zanj tekmujejo; ob tem pa natanko vedo, kaj s kolačem lahko storijo; lahko ga pojedo, podarijo ali prodajo. Ko nekdo kolač poje, ga podari ali ga proda, kolača nima več, Še več, 
tudi tisti, ki je kolač proizvedel, tedaj z njim ne more več razpolagati. Tako je s stvarnimi dobrinami.

\section{ZNANJE JE NEIZČRPEN VIR, KI SE Z UPORABO BOGATI}

Kako pa je z znanostjo in znanstvenimi nasledki? Povsem drugače! Daniele Blondel nas opozori, da znanost znanje pomnoži. Če nekdo znanje, ki ga je proizvedel, prenese na drugega, to še ne pomeni, da ga sam ne bo mogel več uporabljati. Še bolj čudežno je, da se $z$ uporabo znanje ne obrabi, marveč ravno nasprotno, z uporabo bogati. Sleherno znanje namreč vsebuje vsa druga znanja, ki so se vanj integrirala, še preden smo ga dali od sebe, in vsebuje vsa tista znanja, ki se bodo vanj še integrirala v prihodnje. Kako ljudje povečamo svoje znanje? Tako, da skupaj delamo. ${ }^{2}$ Znanje je namreč neizčrpen vir, ki ga je nemalokrat moě izkoriščati povsem brezplačno. Denimo tisto, ki se pretaka med učencem in učiteljem, med mojstrom in vajencem, med sodelavci, med bolj vednimi in manj vednimi, med vednimi in drugače vednimi. Pa tudi med znanstvenimi ustanovami in Znanje bogati šele
z uporabo. drugimi institucijami ter posamezniki. Govorimo o ekonomiji eksternalij, pravi Daniele Blondel. Eksternalija pomeni, da nekateri posamezniki, podjetja, regije ali države lahko uporabijo neko dobrino, ne da bi jih ta dobrina kaj stala. V tem primeru dobrina obstaja $\mathrm{V}$ okolju ali jo je proizvedel nekdo drug, in sicer $\mathrm{v}$ druge namene, pa je prišlo do nekakšne pomnožitve uporabe te dobrine neodvisno od tega, čemur je bila sprva namenjena. Znanje je namreč moč uporabiti na mnogotere načine bla bla bla bla bla bla bla bla bla bla bla bla bla bla bla bla bla bla bla bla bla bla bla bla bla bla bla bla bla bla bla bla bla bla bla bla bla bla bla bla bla bla bla bla bla bla bla bla bla bla bla bla bla bla bla bla bla bla bla bla bla bla bla bla bla bla bla bla bla bla bla bla bla bla bla bla bla bla bla bla bla bla bla bla bla bla bla bla bla bla bla bla bla bla bla bla bla bla bla bla bla bla bla bla bla bla bla bla Bla bla bla bla bla bla bla bla bla bla bla bla bla bla bla bla bla bla bla bla bla bla bla bla bla bla bla bla bla bla bla bla bla bla bla bla bla bla bla bla bla bla bla bla bla bla bla bla bia bla bla bla bla bla bla bla bla bla bla bla bla bla bla bla bla bla bla bla bla bla bla bla bla bla bla bla bla bla bla bla bla bla bla bia bla bla bia bla bla bla bla bla bla bla bla bla bla bla bla bla bla bla bla bla bla bla bla bla bla bla bla bla bla bla bla bla bla bla bla bla bla bla bla bla bla bla bla bla bla bla bla bla bla bla bla bla bla bla bla bla bla bla bla bla bla bla bla bla bla bla bla bla bla bla bla bla bla bla bla bla bla bla bla bla bla bla bla bla bla bla bla bla bla bla bla bla bla bla bla bla bla bla bla by Lif bla bla bla bla bla bla bla bla bla bla bla bla bla bla bla bla bla bla bla bla bla bla bla b. 7 , ila bla bla bla bla bla bla bla bla bla bla bla bla bla bla bla bla bla bila bla bla bla bla bla 1 . Fola bla bla bla bla bla bla bla bla bla bla bla bla bla bla bla bla bla bla bla bla bla bla bla bis a bla bla bla bla bla bla bla bla bla bia bla bla bla bla bla bla bla bla bla bla bla bla bla bla bla to bla bla bla ble bla bla bla bla bla bla bla bla bla bla bla bla bla bla bla bla bla bla bla bla bla bla b. bla bla bla bla bla bla bla bla bla bla bla bla bla bla bla bla bla bla bla bla bla bla bla bla bla bla bi ${ }^{\circ}$ bla bla bla bla bla bla bla bla bla bla bla bla bla bla bla bla bla bla bla bla bla bla bla bla bla bla bl" bla bla bla bla bla bla bla bla bla bla bla bla bla bla bla bla bla bla bla bla bla bla bla bla bla bla ll ( ) bla bla bla bla bla bla bla bla bla bla 5 , 0 bla b a bla bla bla bla bla bla bla bla bla bla bla bla bla bla bla bla bla bi bla bla bla bla bla bla bla bla bla bi bla bla bla bla bla bla bla bla bla br bla bla bla bla bla bla bla bla bla bid bla bla bla bla bla bla bla bla bla bla bla bla bla bla bla bla bla sla blo bla bla bla bla bla bla bla by bla bla bla bla bla bla bla y bla bla bla bla bla bla bla bla bla bla bla bla bla by bla bla bla bla bla bla to bla bla bla bla bla bla I

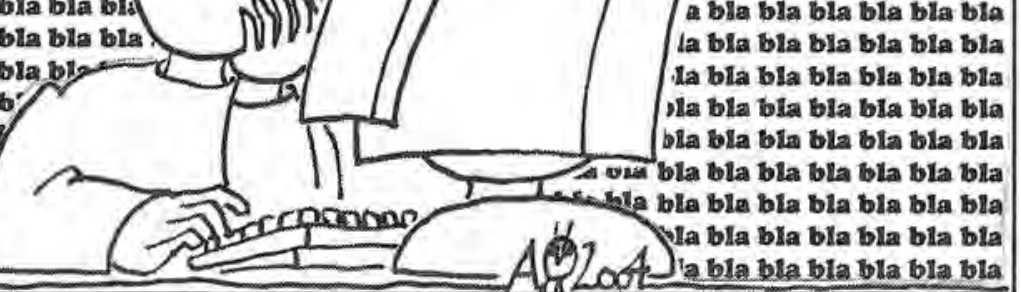

i bla bla bila bila bla bla a bla bla bla bla bla bla tla bila bla bla bla bla bla ola bla bla bla bla bia bla bla bla bla bla bla bla bila bla bla bla bla bla bla bla a bla bla bla bla bla bla la bla bla bla bla bla bla 
in potemtakem je to pogosten vir, v nasprotju s stvarnimi viri, ki veljajo za redke. Vemo, da je eno glavnih gibal današnje ekonomije prav znanje. To je pogostna dobrina; takšna, ki se $z$ uporabo ne izčrpa. Ali to nemara pomeni, da vstopamo $v$ neko čudežno ekonomijo, kjer bi vsakdo našel znanje, ki ga potrebuje, in mu zanj ne bilo potrebno plačati, vsaj ne veliko?

\section{Ameriška podjetja cetrtino sredstev investirajo $v$ znanje,}

se sprašuje Daniele Blondel.

$\mathrm{V}$ nasprotju s temi pričakovanji smo vse pogosteje priča procesom kopičenja znanja, kar veča prepad med posamezniki in narodom, med deželami, regijami in podjetji. O tem priča vse večja vnema $v$ pridobivanju patentov - pa čeprav se to zdi še tako nenavadno - tudi na področju znanosti.

\section{EKONOMIJA STVARNIH DOBRIN NASPROTI EKONOMIJI ZNANJA}

Ekonomija preteklosti je temeljila na naravnih virih. Ti so seveda redki, saj jih je moč izčrpati. Današnja ekonomija pa temelji na virih, ki se ne izčrpajo, saj se gradi na znanju.

V ekonomiji znanja nastajajo novi konkurenčni odnosi.

In prav zaradi dragocenosti znanja prihaja do selitve možganov; iz krajev, dežel, $k i$ imajo malo kognitivnih virov, dela ustanov, ki jih plačujejo davkoplačevalci, po tistem pa te javne podatke zadržijo zgolj zase ali pa jih prodajo za občutno višjo ceno, kot so jih nasledki stali ob nakupu.

$\mathrm{V}$ ekonomiji blagovne menjave je predmet menjave stvarna dobrina. Tudi potrošnja je potrošnja stvarnih dobrin. Kaj torej v takšni ekonomiji ustvari gospodarsko rast? Povečanje proizvodnje stvarnih dobrin na glavo prebivalca.

$\mathrm{V}$ ekonomiji znanja pridobimo znanje in pri tem pomembno vlogo odigra naše družinsko in kulturno okolje. Izobrazba, ki jo pridobimo zunaj podjetja, ipd. V ekonomiji znanja torej znanje pride $v$ podjetje od drugod, denimo iz izobraževalnih ustanov, okolja itd. Leta 1997 je v ZDA 35 odstotkov dodane vrednosti prihajalo iz sektorjev, ki temeljijo na znanju, bodisi da gre za proizvajalce znanja ali uporabnike znanja. Če preučimo naložbe, pravi Daniele Blondel, pa so podatki še bolj zgovorni. Lahko rečemo, da ameriška podjetja četrtino svojih sredstev naložijo prav $v$ znanje.

Tedaj ni nenavadno, da so naložbe, proizvodnja in zaposlovanje v sektorjih, ki proizvajajo in uporabljajo znanje, postali eno glavnih gibal gospodarstva. se ti selijo tja, kjer jih imajo že veliko. Znanje se spreminja v naložbo, kar onemogoča, da bi ga svobodno uporabljali in ga stem bogatili. Zasebna ekonomija namreč danes $\mathrm{z}$ znanjem veča dobiček. Nenazadnje tudi tako, da zaposluje ljudi, ki so si nekje drugod, v neki drugi državi ali na neki drugi celini, v nekih drugih institucijah, z javnimi ali lastnimi sredstvi pridobili izobrazbo. Dobiček veča tudi z nasledki raziskovanja javnih raziskovalnih ustanov. Nemalokrat se zgodi celo, da zasebna podjetja odkupijo nasledke raziskovalnega

\section{POVEZAVA RAZNOTERIH ZNANI JE V DOBRO EKONOMIJI}

Avtorica poudari, da ne gre za teoretično znanje, za mrtve informacije, ki jih je moč najti na internetu. $\mathrm{V}$ znanju, ki je plodno za ekonomijo, se prepletajo štiri temeljne vrste znanja, ki se neprestano povezujejo med seboj. Prepletajo se v znanjih ali zmožnostih slehernega posameznika in organizacije: (1) teoretično znanje, (2) znanje o tem, kako se kaj naredi (angl. know-how), (3) znanje o tem, kaj se naredi (informacije, podatki na internetu, v podatkovnih bazah) in (4) znanje o odnosih (vedeti, kdo je kdo, kdo kaj pomeni, 
na koga se je moč obrniti). Ta znanja so plod izobrazbe, okolja in del, ki jih človek opravlja.

Največ potrebnih znanj pridobimo z (1) učenjem z opravljanjem dela ali dejavnosti (angl. learning by doing), (2) učenjem ob uporabi znanja (angl. learning by using) in z (3) učenjem ob interakciji z drugimi.

Kako upravljati z viri znanja? se še sprašuje Daniele Blondel. Vsekakor ne gre za upravljanje denimo po posameznih etapah, $\mathrm{z}$ aplikacijo modelov, uporabo standardov kakovosti ipd. ${ }^{3}$ Pridobljena znanja in spretnosti so namreč integrirani $\mathrm{v}$ ljudeh ali kolektivih, nabrali so si jih s praktičnim delom. Gre za osebna in teritorialno omejena, lokalna znanja. Gre za lokalne zmožnosti, ki nastanejo iz prakse dela ali prakse socialnih odnosov $\mathrm{v}$ danem okolju.

Če podjetja želijo proizvesti znanje, morajo v pridobivanje znanja investirati. Znanje stane. Tako so se $v$ ekonomiji znanja pojavili tudi novi konkurenčni odnosi.

\section{ČLOVEŠKI KAPITAL IN NOVI KONKURENČNI ODNOSI}

Proizvajalci danes tekmujejo tako, da zmanjšujejo stroške in/ali izboljšujejo izdelke za kupce, ki so že tako zasičeni z nestvarnimi dobrinami. Podjetja so konkurenčna, če so prepoznavna, drugačna. Zato poskušajo brezplačno pridobiti zunanja znanja, tista torej, ki jih proizvedejo drugi in njihovemu izdelku dodajo vrednost.

Ta znanja se skrivajo v človeškem kapitalu, četudi je ta izraz barbarski, četudi ni prav nič lep, je res, da v današnji ekonomiji vrednost izdelka povečujejo prav ljudje s svojimi zmožnostmi. V tem jih je moč primerjati z drugimi oblikami kapitala. Človeški kapital je težko pridobiti in znati je treba sodelovati z ljudmi, ki v sebi ta kapital nosijo. In tako se v tej novi ekonomiji sproža agresivnost, besno iskanje ljudi z znanjem, kar postane delo loveev na glave. Ekskluzivnost človeških virov - kapitala - si je moč pridobiti le tako, da jih odvzamemo drugemu. Še več, vzpostavile so se tudi oblike selektivnega sodelovanja, Ljudje sodelujejo v mrežah. Proizvajajo v mrežah. Sodelujejo $s$ tistimi, ki lahko najbolje razširijo eksternalije. Tu sodelovanje ni stalno, vzpostavi se selektivno glede na naloge in zahteve. Sodelovanje $v$ mre-

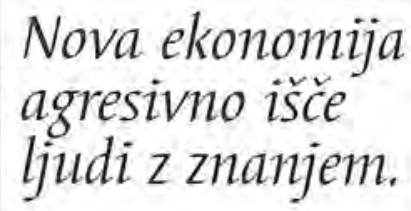
žah proizvaja znanje, drugačno od tistega, ki se je nekoč rojevalo znotraj podjetij. Tako se vzpostavljajo mreže odličnosti, kamor se vključijo najboljši, pa tudi mreže tistih, ki se v mreže odličnosti ne znajo povzpeti.

doc. dr. Dušana Findeisen 